\title{
Minimally Invasive Single-Port Endoscopic Resection of Forehead Osteomas - Case Report and Literature Review
}

\author{
Tiago Neto*, Lígia Coelho, José Soares, Manuel Sousa, Sara Martins and Frederico Martins \\ Department of Maxillofacial Surgery, Centro Hospitalar Universitário São João, Portugal
}

\begin{abstract}
Background: Forehead osteomas are benign bony tumors cosmetically troubling to patients.

Objectives: To review the literature and to further show the feasibility of an endoscopic approach to osteomas of the forehead.

Methods: Male patient, seeking removal of $1 \times 1 \mathrm{~cm}$ forehead osteoma for aesthetic reasons. We used an endoscopic approach using one $1.5 \mathrm{~cm}$ incision, $3 \mathrm{~cm}$ above the hairline. We also performed a systematic review of the Englishlanguage literature dating back 10-years.

Results: The osteoma was removed without complication and with good aesthetic results. A single-port endoscopic approach is safe and can achieve good aesthetic and therapeutic results, complications are infrequent and usually transient.

Conclusions: The endoscopic approach is a reliable and safe approach for osteomas of the forehead. Since pa-tients' motivation for removal is mainly aesthetic, the endoscopic approach seems to be the obvious choice because it provides similar results to the direct excision without leaving a noticeable scar.
\end{abstract}

Keywords

Osteoma, Endoscopic, Forehead, Frontal Bone, Minimally Invasive, Single-Port and Facial Plastic Surgery

\section{Introduction}

Osteomas are benign, slow-growing bony tumors that occur with an incidence of $0.014-0.43 \%$ [1]. They are the most common tumor of the cranial vault and facial skeleton [2].

Most osteomas are asymptomatic. Patients usually present with an aesthetic concern although rarely they may cause localized pain and headache [3]. The most common presentation is a single, firm, and immobile mass; however, multiple osteomas may be present (e.g. Gardner syndrome) [4].

The etiology of osteomas is controversial. Some authors have suggested they arise from embryological rests or hamartomas; others believe they are complication of trauma or infection. A history of local trauma occurs in as many as $30 \%$ of cases [5].

Osteomas occur independent of race. Age correlates with incidence of osteoma, but not with size. Some studies suggest a female predominance, but this might be because women tend to seek help for cosmetic reasons more often than men.

Osteoma must be distinguished from other types of lesions, including the more commonly occurring lipoma. Sewell, et al. compiled an exhaustive list of possible differential diagnoses for osteoma [3].
Excision is the preferred treatment for osteomas because they rarely recur and it can provide a satisfactory cosmetic result [4]. Classic management is direct excision; excision via coronal approach is rarely performed [5]. Since introduced by Onishi [6] in 1995, the endoscopic approach is becoming the standard in the management of forehead masses.

\section{Methods}

We conducted a PubMed database search using the keywords: "osteoma", "endoscopic", "forehead" and "frontal bone." Only articles from the last 10-years and in the English language were included. Relevant references from the articles found in the search were also included.

*Corresponding author: Tiago Neto, Department of Maxillofacial Surgery, Centro Hospitalar Universitário São João, Hernâni Monteiro, 4200-319 Porto, Portugal

Accepted: October 06, 2020

Published online: October 08, 2020

Citation: Neto T, Coelho L, Soares J, et al. (2020) Minimally Invasive Single-Port Endoscopic Resection of Forehead Osteomas - Case Report and Literature Review. J Cosmet Surg 1(1):1-4 


\section{Results}

The results of the literature review are shown in the table. Our patient was a 36 -year-old man who wanted a $1 \times 1 \mathrm{~cm}$ osteoma of his forehead. Removed because he was concerned about his appearance. We used a single-port approach with

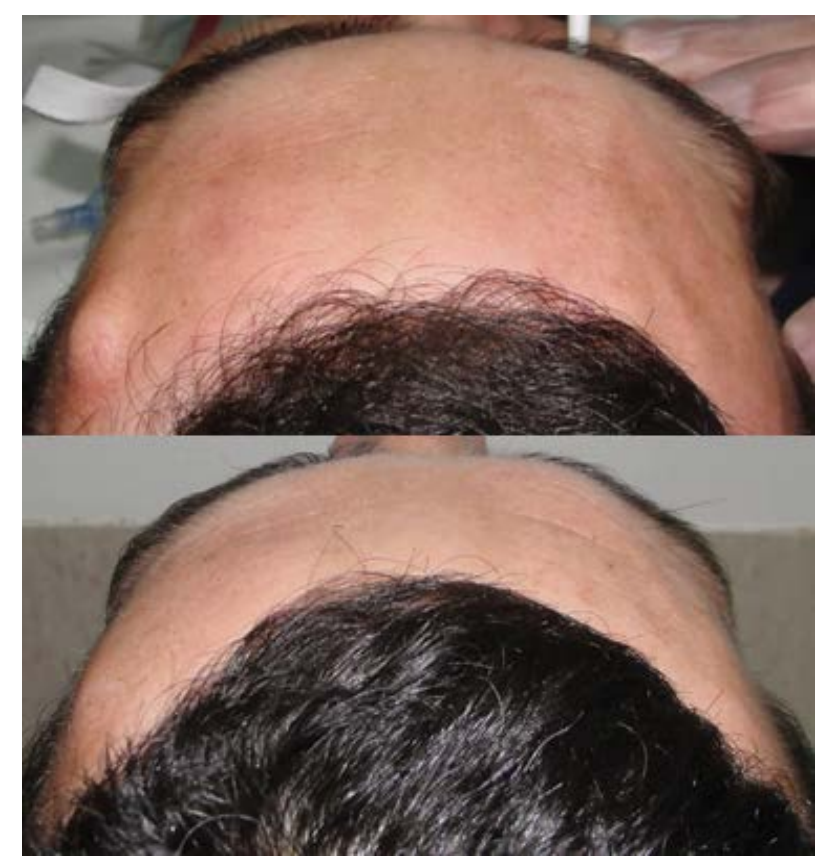

Figure 1: Pre and post-operative photo of the patient with complete aesthetic removal of the mass. one $1.5 \mathrm{~cm}$ incision made $3 \mathrm{~cm}$ above the hairline. The tumor was completely removed and there were no complications. The figures show a comparison between the pre- and post-operative appearance (Figure 1), the pre-operative CT scan (Figure 2) and the intra-operatory endoscopic photos of the removal of the osteoma (Figure 3).

\section{Discussion}

Forehead nodules should be accessed for firmness, mobility, and reducibility. CT is the gold standard for bony anatomy while MRI can be used when further study of soft tissues is needed [3].

There are several advantages of an endoscopic approach. The lesion can be removed without leaving visible scars over the lesion, which would be unavoidable if removed via direct excision [5]. Likewise, endoscopic removal eliminates the risk of skin discoloration, which is particularly important in patients prone to hypertrophic/keloid scarring. Because dissection occurs in a periosteal plane, the frontal branch of the facial nerve and cutaneous nerves are preserved, which reduces post-operative numbness and neuroma formation. Horizontal incisions in the direct approach risk damaging this sensory innervation. The length of hospital stay also tends to be shorter with endoscopic vs. direct surgical approaches [4].

There are some disadvantages to endoscopic frontal osteoma excision, however. Endoscopic removal is associated with an increased risk of hematoma/seroma compared to the direct approach [5]. This problem is potentially magnified if the lesion is relatively far from the hairline (e.g. high hairli-

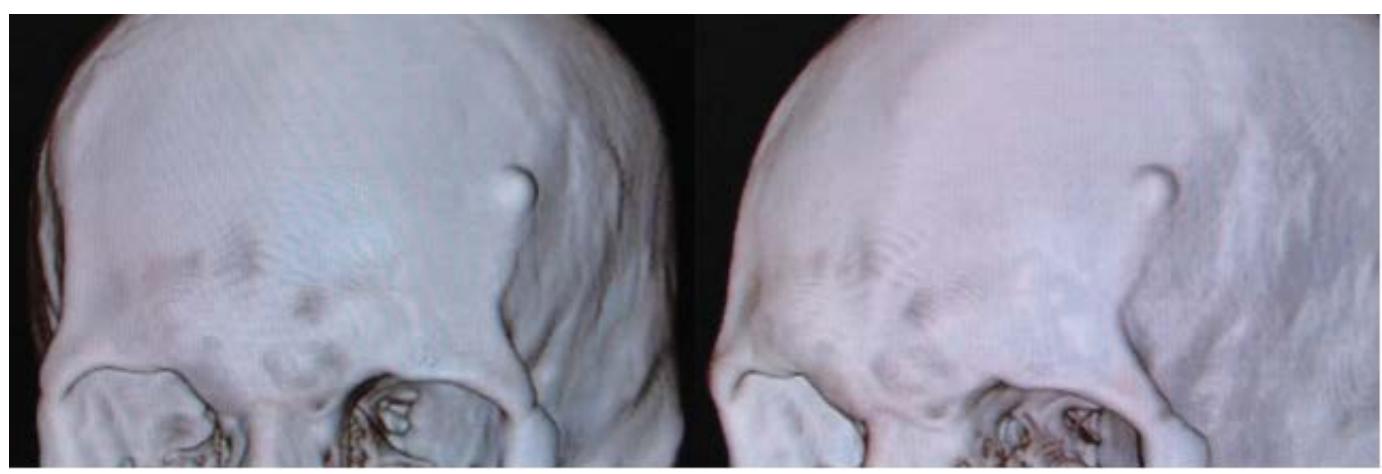

Figure 2: Pre-operative CT scan.

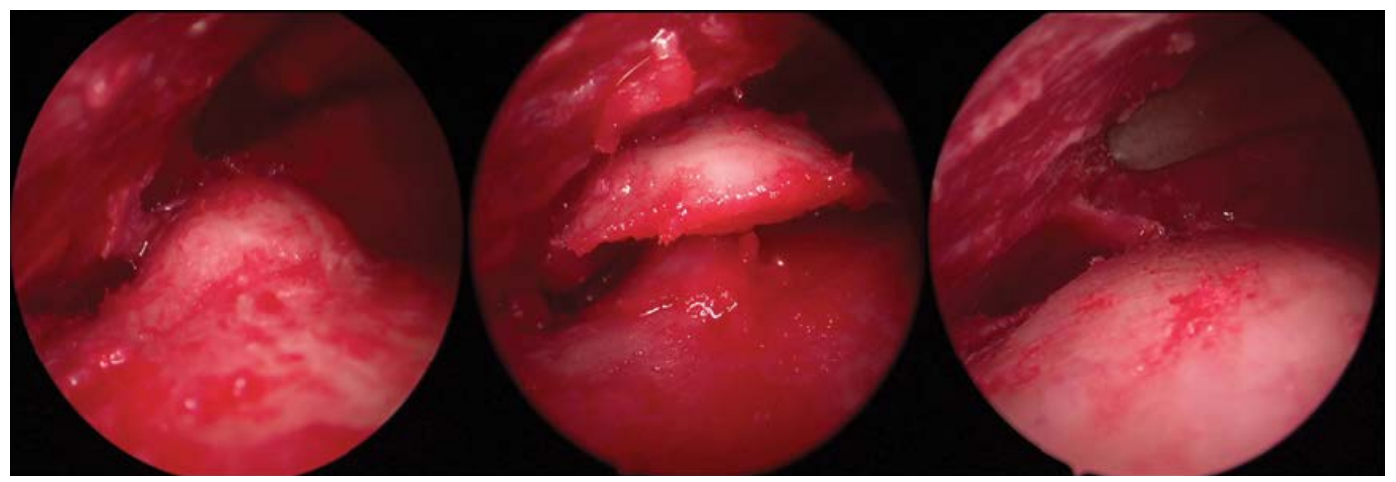

Figure 3: Intra-operative endoscopic images. 
Citation: Neto T, Coelho L, Soares J, et al. (2020) Minimally Invasive Single-Port Endoscopic Resection of Forehead Osteomas - Case Report and Literature Review. J Cosmet Surg 1(1):1-4

Table 1: Reported cases of endoscopic resection of forehead osteomas.

\begin{tabular}{|c|c|c|c|c|c|}
\hline Group & $\mathbf{n}$ & Entry Points & Operative time & Complications & Notes \\
\hline Oyer, et al. [5] & 1 & 2 & - & None & $\begin{array}{l}\text { Pediatric case after } \\
\text { trauma; two additional } \\
\text { lesions where found } \\
\text { during the procedure }\end{array}$ \\
\hline Hsiao, et al. [8] & 10 & 1 & $27 \mathrm{~min}$ & None & Blind dissection \\
\hline Lai, et al. [10] & 6 & 1 & $60 \mathrm{~min}$ & None & \\
\hline Jung, et al. [9] & 1 & 1 & $\begin{array}{l}30 \text { min more than } \\
\text { direct incision }\end{array}$ & None & $\begin{array}{l}\text { Not only osteomas; } 1 \\
\text { osteoma, } 6 \text { lipomas, } 1 \\
\text { pilomatrixoma }\end{array}$ \\
\hline Meningaud, et al. [11] & 5 & 3 & $20-40(30) \mathrm{min}$ & None & \\
\hline Foustanos, et al. [12] & 9 & 3 & - & None & $\begin{array}{l}\text { Procedure done during } \\
\text { endoscopic brow lift }\end{array}$ \\
\hline Serra-Mestre, et al. [4] & 9 & 1 & - & None & \\
\hline Guerrissi, et al. [13] & 6 & 1 or 2 & - & 2 hematomas, & \\
\hline $\begin{array}{l}1 \text { paresis of the frontal } \\
\text { nerve }\end{array}$ & $\begin{array}{l}\text { Not only osteomas; } 6 \\
\text { osteomas, } 20 \text { lipomas. }\end{array}$ & & & & \\
\hline \multicolumn{6}{|l|}{$\begin{array}{l}\text { Paresis resolved } \\
\text { spontaneously after } 5 \\
\text { months }\end{array}$} \\
\hline Im, et al. [2] & 45 & 2 & $13-30(20) \mathrm{min}$ & 4 recurrences, & \\
\hline \multicolumn{6}{|l|}{2 hematomas, } \\
\hline 1 wound dehiscence & $\begin{array}{l}\text { Not only osteomas; } 45 \\
\text { osteomas, } 77 \text { lipomas, } 24 \\
\text { dermoid cysts, } 6 \text { others; }\end{array}$ & & & & \\
\hline \multicolumn{6}{|l|}{$\begin{array}{l}\text { More patient satisfaction } \\
\text { when compared to the } \\
\text { direct approach }\end{array}$} \\
\hline Sadick, et al. [7] & 13 & 2 & $36 \mathrm{~min}$ & 1 alopecia & $\begin{array}{l}\text { Not only osteomas; } 13 \\
\text { osteomas, } 18 \text { lipomas, } 2 \\
\text { dermoid cysts, } 1 \text { others; } \\
\text { Alopecia resolved within } 2 \\
\text { months }\end{array}$ \\
\hline Neto, et al. & 1 & 1 & $22 \mathrm{~min}$ & None & \\
\hline
\end{tabular}

ne) [7]. Importantly, surgeons may choose to enter at a forehead rhytid, instead. Endoscopic removal requires specialized equipment and increased surgery time, a concern that becomes less significant as the surgeon gains experience. While nerve damage is less of a concern with the endoscopic approach, it is still possible. The deep branch of the supraorbital nerve is particularly vulnerable. No incisions should be made in the zone between the superior temporal line and a line 2 $\mathrm{cm}$ medially [8].

The number of entry points (1, 2 or 3 ; Table 1 ) is up to the surgeon and is usually of no concern. However, the surgeon must be aware that nerve damage is most likely to occur at the incision site. Consequently, a smaller number of ports theoretically present fewer risks [9].

\section{Conclusions}

The endoscopic approach is a viable treatment option for osteomas. The chief concern of most patients is aesthetic, so a direct approach to excision that may leave a visible scar is less favorable. A single-port endoscopic approach is safe and can achieve good aesthetic and therapeutic results. While there are advantages and disadvantages to endoscopic techniques that must be considered, complications are infrequent and usually transient. Although the procedure requires training and specialized equipment, we believe the endoscopic approach is worth the investment and will soon become the gold standard for forehead lesions.

\section{References}

1. Patel TR, Borah GL (2004) Frontal bone periosteal osteomas. Plast Reconstr Surg 114: 648-651.

2. Im JT, Park BY, Lim SY, et al. (2014) Endoscopic excision of benign facial Tumors: A Decade of experience with 152 patients. Ann Plast Surg 72: 556-559.

3. Sewell LD, Adams DC, Marks VJ, et al. (2008) Subcutaneous forehead nodules: Attention to the button osteoma and frontalis-associated lipoma. Dermatol Surg 34: 791-798.

4. Serra-Mestre JM, Serra-Renom JM, D'Andrea F, et al. (2015) En- 
doscopic management of osteomas of the forehead. Br J Oral Maxillofac Surg 53: 1032-1034.

5. Oyer SL, Patel KG (2012) Endoscopic brow approach for frontal osteoma in a pediatric patient. Int J Pediatr Otorhinolaryngol 76: 1211-1213.

6. Onishi K, Maruyama Y, Sawaizumi M, et al. (1995) Endoscopic excision of forehead osteoma. J Craniofac Surg 6: 516-518.

7. Sadick H, Huber M, Perkins SW, et al. (2014) Endoscopic forehead approach for minimally invasive benign tumor excisions. JAMA Facial Plast Surg 16: 352-358.

8. Hsiao F-Y, Ma H (2015) Single-port endoscope-assisted resection of forehead osteoma. Formosan Journal of Surgery 48: 57-61.
9. Jung S, Jung SW, Koh SH, et al. (2016) Forehead Mass Removal by Endoscopic Approach. J Craniofac Surg 27: e215-e217.

10. Lai CH, Sun IF, Huang SH, et al. (2008) Forehead osteoma excision by endoscopic approach. Ann Plast Surg 61: 533-536.

11. Meningaud JP, Toure G, Lantieri L (2008) Endoscopic resection of osteoma of the forehead. Scand J Plast Reconstr Surg Hand Surg 42: 286-289.

12. Foustanos A, Zavrides $H$ (2007) Endoscopic resection of forehead osteomas. Br J Oral Maxillofac Surg 45: 392-395.

13. Guerrissi JO (2015) Video-assisted resection in benign frontal tumors J Craniofac Surg 26: e31-e33. 